\title{
Cesarean Section followed by myomectomy in a pregnancy complicated by left intraligamentous myoma (a case report)
}

\author{
Arifuddin Djuanna
}

\begin{abstract}
Abstrak
Seorang ibu primigravida berumur 20 tahun hamil 38 minggu dengan komplikasi tumor uterus intraligamenter kiri yang besar dan padat. Operasi dimulai dengan seksio sesarea untuk melahirkan bayi. Diberikan uterotonika intramural dan kontraksi uterus baik; diberikan infus oksitosin intra dan postoperatif selama 24 jam. Teknik jahitan "double circle" dilakukan pada bagian lateral mioma sebelum miomektomi. Tidak diberikan transfusi darah. Histopatologinya adalah leiomioma. Pasien tersebut pulang dalam keadaan sehat 4 hari setelah operasi. (Med J Indones 2004; 13: 66-8)
\end{abstract}

\begin{abstract}
A 20-year-old primigravida with $38^{\text {th }}$ weeks of gestation complicated with a left large solid intraligamentous uterine tumor. The operation started with lower segment cesarean section to delivere the fetus. Intramural uterotonica was given and the uterus contracted well; intra- and up to 24 hours post-operatively oxytocin infusion was administered. Double circle stitching technique was performed on lateral side of the mioma before starting myomectomy. No blood transfusion was given. The histopatological report was leiomyoma. She was discharged in healthy condition 4 days post-operatively. (Med J Indones 2004; 13: 66-8)
\end{abstract}

Keywords: Myomectomy, cesarean section, intraligamentous myoma

Uterine leiomyomas are the most common uterine neoplasms. They are benign proliferation of smoothmuscle cells and fibrous connective tissue that arise from the uterine smooth muscle. They are noted clinically in $20 \%$ - $30 \%$ of women older than 30 years of age and are found in up to $75 \%$ of hysterectomy specimens. ${ }^{1}$ In Indonesia, Tangkudung and Raharjo reported that the prevalence of leiomyomas are $10.30 \%$ and $11.87 \%$ respectively, of all gynecologic patients. Other study reported that the occurance of leiomyomas was up to $40 \%$ of women after turning 35 years old. ${ }^{2}$

In most cases, uterine leiomyomas do not necessarily jeopardise pregnancy. However, these pregnancies will have leiomyoma related-complications. These complications appear to be related to size, number, and site of leiomyomas. ${ }^{3-7}$ Uterine leiomyomas in

Department of Obstetrics and Gynecology, Faculty of Medicine, University of Hasanuddin, Makassar, Indonesia pregnancy are found in approximately $1 \%$, excluding undetectable small leiomyomas. ${ }^{3}$ While Merrill reported that the incidence of leiomyoma during pregnancy varies from $0.3 \%$ to $7.2 \%$. $^{7.8}$

The effects of uterine leiomyomas on women and pregnancy are as follows : causing infertility, increasing risks of abortion, producing fetal malpresentation, obstructing progress of labour, causing uterine inertia and atonia, causing difficulties in delivering placenta, and inhibiting uterine involution process during parturition. ${ }^{3-7}$ Loeffler and Noble reported that $1 / 3$ of the 180 women with myomectomy experienced abortion during their pregnancies, only 41 patients gave birth and $25 \%$ of them underwent cesarean section. $^{7,8}$

The size of leiomyomas during pregnancy tends to enlarge due to the presence of edema and degeneration, and not due to the proliferation process of tumor. ${ }^{6-9}$ The rapid growth of tumor particularly occurs in the first few months of pregnancy, while red degeneration occurs in both period of pregnancy and 
parturition. In addition, in the rarely cases torsion of pedunculated tumors can cause an acute abdomen syndrome. $^{9-12}$

\section{CASE}

A 20-year-old primigravida was referred to our antenatal clinic. Her uterine size was larger than what was expected for her period of amenorrhoea. An ultrasound examination revealed a single fetus corresponding to 38 weeks and a left large solid intraligamentous uterine tumor.

The operation started with lower segment cesarean section to deliver a male infant, weight 2.450 grams, with an Apgar score of 8 at one minute and 10 at five minutes. Intramural uterotonica (10 units) was given. After the uterine incision was closed, and the uterus contracted well, intra- and up to 24 hours postoperatively oxytocin infusion was administered.

Double circle stitching technique was performed before starting myomectomy. A solid tumor size 17 $\mathrm{cm} \times 15 \mathrm{~cm} \times 12 \mathrm{~cm}$ was enucleated with minimal blood loss. No blood transfusion was given. The histopatological report was leiomyoma. She was discharged in healthy condition 4 days post-operatively.

\section{DISCUSSION}

Uterine leiomyoma is a benign uterus tumor, which consists of uterine muscle cell and its tissue. Depending on the composition, it could be benign, compact, and located in diverse areas. Due to the large size and the change in vascularisation, uterine leiomyoma could experience hyalin, red and cystic degeneration. ${ }^{1,8,10}$

Uterine myomas are found in approximately 0,3 to $2,6 \%$ of pregnant women. The vast majority of these myomas is small, asymtomatic, and often just a chance finding even since the use of ultrasonography has become widespread. Myomas do not necessarily jeopardise pregnancy. However, approximately $10-$ $40 \%$ of these pregnancies will have myoma related complications. These complications appear most often to be related to the size and site of the myoma, in particular with regard to placental site. Myoma related complications are spontaneous abortion, premature rupture of membranes, preterm labour, fetal malpresentation, pospartum hemorhage, cesarean delivery and post cesarean hysterectomy. In this case the location of myoma was intraligamentous, so the myoma did not jeopardise pregnancy. In some cases, myoma did not jeopardise the pregnancy and the baby can even be delivered transvaginally safely. Morbidity and mortality caused by postpartum hemorrhage increase in certain cases. Manuaba ${ }^{11}$ reported mortality caused by postpartum hemorrhage in pregnancy complicated with myoma after a normal vaginal delivery. Chung et $\mathrm{al}^{12}$ reported a myomectomy in the treatment of postpartum haemorrhage after a normal vaginal delivery. Based on the case report some authors do not recommend myomectomy during cesarean section. The reason is increased vascularity of the gravid uterus, thus myomectomy performed in pregnancy has been reported to be associated with greater risk of haemorrhage and the need for blood transfusion. ${ }^{7}$ But If the myoma is still in the uterus, it also can increase posibility of postpartum hemorrhage. ${ }^{9,11-13}$ The main reason why in this case we performed a cesarean was section because the head of the baby can not engage due to obstruction by the myoma. Some author also reported that if the myoma complicated the labour progress, cesarean section become the only choice.

The case described above illustrate that cesarean myomectomy can be safely performed. This case is one case of the prospective clinical trial conducted between January 1996 and January 2002 in several hospital and maternal hospital in Makassar, there had been 66 cases in which cesarean myomectomy had been performed. ${ }^{17}$ Double circle stitching technique was performed before starting myomectomy to minimize haemorrhage. Other known technique to minimize harmorrage using vasopressin injection or using penrose drain or catheters as tourniquets to compress the uterine vasculature. ${ }^{7}$ After cesarean myomectomy retraction of the uterine muscle was enhanced by oxytocin infusion intra- and postoperatively (continued for 24 hours).

Such operation should only be carried out with optimal anaesthetic facilities and by an experienced surgeon who has already had experience in interval myomectomy in non pregnant women, as he may on occasion be confronted by considerable blood loss.

\section{CONCLUSION}

With adequate experience and the use of high dose oxytocin infusion (intra- and post-operatively), myomectomy at cesarean section is not as hazardous as many now believe. 


\section{REFERENCES}

1. Fenner DE. Fibroids: basic information. In: Bieber EJ, Maclin VM, editors. Myomectomy. 1st ed. Massachusetts: Blackwell Science; 1998. p. 1 - 11.

2. Joedosaputro MS. Tumor jinak pada alat genital. In: Wiknjosastro H, Saifuddin AB, Rachimhadhi T, editors. Ilmu Kandungan. 2nd ed. Jakarta: Yayasan Bina Pustaka; 1997. p. 338-45.

3. Febo G, Tessarolo M, Leo S, Arduino S, Wiesris T, Lanza L. Surgical management of leiomyomata in pregnancy. Clin Exp Obstet Gynecol 1997;24(2):76 - 8.

4. Michalas SP, Oreopoulou FV, Papageorgiou JS. Myomectomy during pregnancy and caesarean section. Hum Reprod 1995;10(7):1869-70.

5. Roberts WE, Fulp KS, Morrison JC, Martin JN. The impact of leiomyomas on pregnancy. Aust NZ J Obstet Gynaecol 1999;39(1):43 - 7.

6. Rosati P. The volumetric changes of uterine myomas in pregnancy[Abstract]. Radiol Med (Torino) 1995; 90(3):269-71.

7. Bieber EJ. Myomectomy by laparotomy. In: Bieber EJ, Maclin VM, editors. Myomectomy. 1st ed. Massachusetts: Blackwell Science; 1998. p. 109 - 13.

8. Merill JA, Creasman WT. Benign lesions of the uterine corpus. In: Danforth's obstetrics and gynecology. 6th ed. Philadelphia: JB Lippincot Comp; 1999. p. 1027 - 39.

9. Vergani P, Ghidini A, Strobelt N, Roncaglia N, Locatelli A, Lapinski RH, et al. Do uterine leiomyomas influence pregnancy outcome? Am J Perinatol 1994;11(5):356-8.
10. Whitfield CR. Benign tumours of the uterus. In: Whitfield $\mathrm{CR}$, editor. Dewhurst's textbook of obstetrics and gynaecology for postgraduates. Victoria: Blackwell Science; 1995. p. 738-46.

11. Manuaba F, Djuana A. Post partum hemorragic in pregnancy complicated with myoma uteri [abstract]. In: Abstract Books The 12th Western Pacific Association of Critical Care Medicine;August 22 - 25, 2002; Nusa Dua, Bali. p. 110

12. Chung TKH, Chan MYM, Stock AI. Myomectomy in the treatment of postpartum haemorrhage. BJOG 1994;101:73 -4 .

13. Liu J, Han F, Bian X. Optimal management of postpartum hemorrhage [Abstract]. Chin Med J (Engl) 2001; 114(12):1280-2.

14. Ehigiegba AE, Ande AB, Ojobo SI. Myomectomy during cesarean section. Int J Gynecol Obstet 2001;75:21 - 5 .

15. Kwawukume EY. Myomectomy during cesarean section. Int J Gynecol Obstet 2002;76:183 - 4.

16. Lamy M, Boutin P. Myomectomy combined with a caesarian performed at term[Abstract]. Bull Fed Soc Gynecol Obstet Lang Fr 1965;17(3):236-40.

17. Arifuddin S, Manuaba F, Ronny T, Rauf S, Djuana A. Miomektomi pada seksio sesarea di beberapa rumah sakit dan rumah sakit bersalin di Makassar (laporan pendahuluan)[Abstract]. Maj Obstet Ginekol Indones 2002;26(Supp 1):14 - 5 . 